\title{
Internal articulation of the open work concept
}

\author{
Iulian Bitoleanu \\ National High School Anastasescu, Republiciii Street No 11, Rosiori de Vede, Romania \\ E-mail address: bitoleano_iulian@yahoo.com
}

\begin{abstract}
Study shows multiple valences of aesthetic concept opening in artwork, whose notoriety was due to Umberto Eco. It was mentioned honest rivalry between France and Italy, in terms of pioneering art. Comparative method and the exhibition referencing the music, literature, sculpture, architecture, painting, cinema, applying a single criterion - the opening, leading to equivalence of open work exceptional work, moving, unpredictable, indeterminate, asymmetric but bizarre work, unfinished, unfinished, ambiguous, discontinuous. Anchoring the French cultural space, European (J. P. Sartre, M. Merleau-Ponty, E. Husserl) deepened the theme set forth and conferred substantiality, sense.
\end{abstract}

Keywords: communication effects; aesthetic communication; open work

\section{INTRODUCTION}

France, generator current of so many artistic movements and homeland Barthes friend and rival was the springboard to the concept of "open work" (thanks to Claude Lévi-Strauss), but irrelevant without Eco.

Resounding success will be driven by Umberto Eco, sunrise in a landscape aesthetic and semiotic fast, effervescent, a revanchist Italy artistically, conceptually, where his reputation Croce aroused uncontrollable reverberations thus beneficial. Why, however, in Italy? - skeptics might ask. Explanations should be two, we think. First: because there than anywhere especially in Europe, has cemented a priority crop shape, after celebrating resources Florentine Renaissance personality, engaged in the whirl of artistic phenomena to litter silence of centuries, grave and solemn. Second meant to France, because the early century twentieth century, to bursts by Marinetti's Futurism, "tracer" a vanguards multiple and diffuse, percussive and irritating. Artistic adapters after 1960, when Italy has relapsed and grounded in film (Antonioni), theater (Pirandello) polarizing the attention of Europe obstinate innovative Paris which gave a subdued tone, exact time, for so many centuries, culture and art. His current fund - binomial atomized form to bet on a winner as fashion has become status, legislating temporarily, for a few decades, through Italy rediviva, a monumental Croce, a veritable capital of universal art.

Secondly, in the land of Dante, flourished semiotics (Terraccini - a name often cited), and aesthetics, with the support of Benedetto Croce and Luigi Pareyson has reached unimaginable heights, the sliced "dispute" with France, adherent to the theory and literary criticism, sociology, art by G. Poulet, R. Barthes, G. Genette ... Nowhere in the world there, 
after 1980, many Italian universities semiotics and aesthetics, Palermo, Bologna, Turin to Milan, Genoa, Venice...

Not eventually be revealed that overall aesthetics to individualized musical aesthetics, aesthetics of architecture... a high level of professionalism. So, Umberto Eco has received artistic ground in Italy more than fruitful (Stoica, 2007; Vlăduţescu, 2008; Dima \& Vlăduţescu, 2012; Vintilescu, 2014).

\section{POLISEMY CONCEPT OF "OPEN" INTO WORKS OF ART}

The numerous references to the concept of "open art" found in Opera opened Umberto Eco's essay paper marked distinct cultural evolution at the crossroads of semiotics and aesthetics XX-XXI centuries. We should not expect a smooth study visible, straight, on the contrary, a dense, complex complementary information, nuanced, and even dissonant, contradictory. Favorable reference area "opening" is the art quality of literature, painting, architecture, music to theater, cinema, but does not preclude inventive and fascinating Eco irrevocably non-artistic area, making concessions sport, in this case, fighting, fencing (in the latter cases ). Extrapolating fundamental aesthetic category - sublime, tragic, beautiful, misty, open concept produces suspicion opposite aesthetic indulgence Italian scholar semi-aesthetic manifestations. Definition effigy be housed under the bottom, moving, or work asymmetrical finished, defying the canons, laws, rules, open work is more/less valuable from one situation to another, knowing that everything retail and switchable unpredictable, lacking symmetry crowns an intellectual effort capitalizes artist's imagination (Borowski, 2014 ; David, 2013; Mangra, Cotoc \& Traistaru, 2013; Bosun \& Modrak, 2014).

When Italian aesthetic emblem suggests that open opera opera unfinished, unfinished "inachevée" such exegete says Jules Gritti - of course that eludes axiological criterion that does not remain in the masterpieces. Which, of course, not in the multitude of attempts, the blanks artistic pursuits allegedly professional creators secondary rank. Example with Mallarmé, Petrarch, Dante, Ungaretti, Brecht, French symbolism, sonata dodecaphonic validate contrary endorse value, exceptional work. Exceeds somehow, even slightly the hesitant concept of " open work" aesthetic borders and appropriates a fault in the territory of the axiological?

Work fundamental to semiotics and aesthetics "Opened opera" - Umberto Eco allows detection of several meanings for the concept eponymous title: a "torso", "work model" opera fundamental message, streaked ambiguity, self-reflexive work, work moving form and so on Harnessing suggestions, ideas Luigi Pareyson (Aestethics), R. Barthes (About Racine; Degree zero of writing), Umberto Eco priorities art - form "artwork is a product of an author who holds a "communication network effects so that any consumer can understand possibly through the game again for answers to configuration effects felt as stimulus sensitivity and intelligence, the work itself, as imagined by the original author" (Eco, 1969, p. 47).

The first stop in the realm of music envisages not universally recognized masterpieces, but rather options-let's say-bizarre, sliding to a variety of axiology unprepossessing connected to imperfection and ephemeral: "But it is clear that works like those of Berio or Stockhausen open in a sense less metaphorical and more specifically, vulgar words, are works unfinished" (Eco, 1969, p. 48)

Currently, other explanations, French monographist actually noticed and Jules Gritti, which opened in modernism access works unfinished, unfinished (Gritti, 1991, p. 30), authority to which the Italian specialist is called Abraham Moles. Moreover, musician H. Pousseur flush the finding that open poetic work tends to promote the interpreter acts of conscious freedom, 
to situate him as an active center of a network of relationships inexhaustible... he (to) establish its own form. Understanding music composer-performer outside binomial assumes another actant: listener, music lover endowed with almost magical powers: "... a work of Webern listening, the listener free reorganization and consume a number of relationships within the sound universe that is offered in Scambi (the Pousseur), the consumer organize and structure musical discourse, even for the purposes of producing. Collaborates on doing work" (Eco, 1969, pp. 58-59).

It would seem that the epithet "unfinished" takes only musical meanings in equation near the composer being introduced II element interpreter "unfinished work, which the author entrusts the performer seems more or less like pieces of a game mechanic" (Eco, 1969, p. 48). In Chapter II, poetic speech and information, open area works in music expands the classical sonata assignation, dodecaphonic system, this time intervening shade: opening involves "a probability."

To recognize the subjective factor in the consumption share of art means a deal instantly with the sociology of art, two-stroke: one philosophical, referring to Plato, in his view about painters (the Sophist) and other religious literature on semantics is a message (Hristea \& Colhon, 2012; Avram \& Traistaru, 2014) extracted from a masterpiece or medieval poetics.

Making a flash with the other arts, sculpture and architecture, painting induce the idea that open opera is a work in motion, with samples: motives (furniture) of Calder, Bruno Munari's sails, Faculty of Architecture in Caracas (Venezuela), whose story, classrooms are Sanji, pictures quickly run like a cartoon (Siminică \& Traistaru, 2013; Vlăduţescu, 2013; Colhon, 2013 ; Smarandache \& Vlăduţescu, 2014; Dascălu, 2014).

The phenomenon of moving work in the current cultural situation is not at all limited to the music, but knows interesting events in the field of fine arts, where today we find art objects "themselves having mobility, capacity to reimpose the kaleidoscopic gaze consumer as eternal us" (Eco, 1969, pp. 58-59) In the same area, permissiveness Eco places, besides artistic design, and industrial design in its domain, industrial design gives minimal examples, but obvious works in motion with some furniture, lamps mobile libraries can recompose the different faces, chairs capable of metamorphosis with certain prestige style. occurrence is also the unfinished work, illustrated by "Le livre" of Mallarmé, where the first and last page they correspond, communicate in almost unimaginable symmetry, and not least by his prose J. Joyce, Finnegan's Wake.

Fortified with assiduous reading of Henri Pousseur, renowned esthetician music, opening music, and literature, receives new attributes: indeterminacy, discontinuity, complementarity, and provided moral ambiguity, contrast problematic increase consistency of ideas and persuasion is provided by the author appeal to two benchmarks: E. Husserl ("Meditations cartésiennes") and J. P. Sartre ("L'Etre et le Néant") with steps aimed, on the one hand, the cube - shaped ordered a full and open - and yet, in another way, the work of Proust, the brilliant writer equated with "infinity views possible character inexhaustible" (Eco, 1969, pp. 64-65). The problem of artistic opening moves to the perception of the artwork, which, of course, limits the role of the artist.

New ally of Italian esthetician M. Merleau-Ponty is now with the perception Phénoménologie (Ponty, 1945, pp. 381-383), in inciting debate about it, the universe, faith fulfilled synthesis, perspective, contradiction. The lines are set up, mix in a whole narrative that reaches the mixer fatally interrogative, dissipative, for reason is seduced and transformed into feud ambiguity. The new identity of the work-moving open-work should be interpreted as widening deployable, flexible, dual activation recipient then justified artistically-consumer and spectator in the construction work. 
Here is a concession to the court reading, optimistic, greeted as co-author, since "work should be complete by consumer attitudes" (Eco, 1969, p. 69). Thesis questionable how long does a lot of personal interventions in the structure of the work. Perpetual expansion of open work - as a metaphor - lead to augmentation of artistic knowledge, coupled with the restriction scientific convicted shocking way to penance oblivion, erasing the collective memory "any art form can very well be considered, if not as a substitute for scientific knowledge, at least, as an epistemological metaphor" (Eco, 1969, p. 69). Preferably it would have been Italian esthetician illuminate the intellectual and ally own fictional artist has not always with a fertile imagination. Decoupling of visual arts and sound causes a turning towards art and scenei. So word in theater, Brechtian drama viewer supports collaboration with perceived not as passive ins, static, just devouring culture of art but the manufacturer generator thoughts, delusions, inspired replicas.

Even if the author has no revelation "Opera aperta" contribution to theater director, and why not, the cinema, we'll reveal this truth. Opposite shy with it, expanding into what seems art, sociology of art resuscitation of a triad of author - opera - public, draping, minimizing creator reveals semantic dialectic quite spectacular. Despite some redundancies, harshness, a reflection of the key opening unexpected negative ennobles him stepping on us writer, musician us, our painter, but blessed the dome beauty. Friend, confidant, each time, the artist, the consumer of art - because he is talking about - positively intervene in the process of creation, amprentând and, why not, that elevating work. A privileged interpreter would have (a song), actor or director for theater, film. Chapter "Role plot in prose and theater of the twentieth century" reveals affinities researcher theater of the absurd, including playwrights Ionesco, Beckett, Adamov, with television, hers off cameras, rendering the impression of life; outlines penchant for cinema, especially for the Italian performance by Antonioni's films ("Adventure", "Night"), which"categorically break with traditional structures of plot, in order to present a series of unrelated events dramatic understood conventional sense" (Eco, 1969, pp. 198-199). Intuitions even aged trees, reprehensible, objectionable by various conservative commentators just limiting the arts, I raise the example all back home ie the dramatic work of Luigi Pirandello ("Six Characters in Search of an Author", 1921), another bold pioneer in the European theater.

There are enough reasons that we concur esthetician great vision of Bologna, postulating that the work claimed lends itself open to a "continuous germination of internal relations which the consumer has to discover" real trampoline toward "infinite possible readings" (Eco, 1969, p. 71). Umberto Eco believes that "open work" proceeds of Baroque operas nursery ordered denying the static work definitively unequivocal. Dynamism of Baroque was founded poetic indeterminacy - and, here, the argument is - suffering, convergent poetics cant French symbolism follower of vague resonances, the unexpected horizons (Eco, 1969, pp. 61-64). The richness of meaning to "art opening" chapter records doctrine Zen kind of kickback antiBaroque reaction with target refusal symmetry - identified kabuki theater and - limit! Extrapolating boundary sublime arts and art fencing fight the availability of Hazard, curious to extra-art.

Religion asymmetry (Frunză, 2012; Tabără, 2012; Frunză, 2014) provide remedies for contemporary art panda kitsch, the gloomy weather, Hegel, namely painting, music are offered a bonus, a favor, a chance to perpetuation through ticket authorial unpredictability. Triumph predictability push art to ridiculous, so a solitary variant is the transfiguration daily, decorating with tropes. It confirms that not only art in its epistemological metaphor, the essence and function (Eco, 1969, p. 166 and following). Eco's doctrine is infallible, she knows contradictions, inconsistencies. Conceptual slippage substance amid lurid revelations: compromise with sports scientist with nearta behalf artistic opening. 


\section{CONCLUSION}

Carried on a wave of fantasy of breaking borders U. Eco substitutes pulsation of life, the reality of causality removing from the equation the example of opening: Life in its immediate spontaneity is not only opening but causality - this time does not contradict Eco. In this way, the film answered Adventure causal orders "causal - will", "will calculated", indeterminacy and again field of possibilities.

\section{References}

[1] R. Barthes (1964). Essais critiques. Paris: Seuil.

[2] V. Tabără (2012). Dezvoltarea capacităţii administrative. Bucureşti: Editura CH Beck.

[3] Andrzej Borowski, International Letters of Social and Humanistic Sciences 14 (2014) 7-17.

[4] Petre Bosun, Vladimir Modrak International Letters of Social and Humanistic Sciences 14 (2014) 66-72.

[5] P. Cornea (1988). Introducere în teoria lecturii. Bucureşti: Editura Minerva.

[6] M. G. Mangra, E. A. Cotoc, A. Traistaru (2013). Sustainable Economic Development Through Environmental Management Systems Implementation. Journal.

[7] Ş. Vlăduţescu, E. M. Ciupercă (2013). Next Flood Level of Communication: Social Networks. Aachen: Shaker Verlag.

[8] Andrzej Borowski, International Letters of Social and Humanistic Sciences 14 (2014) $33-41$.

[9] Eco U. (1969). Opera deschisă. Formă si indeterminare in poeticile contemporane. Bucureşti: ELU.

[10] Ştefan Vlăduţescu, International Letters of Social and Humanistic Sciences 10(2) (2014) 100-106.

[11] Dumitru Vladut (1998). Figuri sintactice repetitiv-adjunctive In stilul stiinfific romanesc din secolul al XIX-lea. Filologie.

[12] Stoica D. S. (2007). Political Correctness and Wooden Language. Revista Transilvană de Ştiinţe ale Comunicării, 5; 60-64.

[13] Ş. Vlăduțescu (2013). Principle of the Irrepressible Emergence of the Message. Jokull.

[14] T. De Lauretis (1981). Umberto Eco. Firenze: La nuova Italia.

[15] F. Hristea, M. Colhon (2012). Feeding syntactic versus semantic knowledge to a knowledge-lean unsupervised word sense disambiguation algorithm with an underlying Naïve Bayes model. Fundamenta Informaticae.

[16] Ştefan Vlăduţescu (2013). Message as Fundamental Discursive Commitment of Communication. Journal.

[17] Andrzej Borowski, International Letters of Social and Humanistic Sciences 11 (2014) 1-168. 
[18] J. Gritti (1991). Umberto Eco. Paris: Editions Universitaires.

[19] Ioan David (2013). Presă şi cultură (Press and Culture). Timiţoara: David Print.

[20] Ştefan Vlăduţescu (2013). Three Diachronic Paradigms of Communication. International.

[21] J. Kristeva (2003). Le plaisir du texte. Paris: Seuil.

[22] I. Iancu, N. Constantinescu, M. Colhon, International Journal of Computers Communications \& Control 4(5) (2010) 525-531.

[23] Ioan Constantin Dima, Ştefan Vlăduţescu (2012). Persuasion elements used in logistical negotiation: Persuasive logistical negotiation. Saarbrucken: LAP Lambert Academic Publishing.

[24] I. Mavrodin (1982). Poetică si poietică. Bucureşti: Editura Univers.

[25] Marian Siminică, Autrelia Traistaru (2013). Self-Directed Learning in Economic Education. International.

[26] Ştefan Vlăduţescu (2014). Eight Computational-Communicative Operations of Building Information. Mitteilungen Klosterneuburg

[27] Andrzej Borowski, International Letters of Social and Humanistic Sciences 3 (2013) 69-74.

[28] Ştefan Vlăduţescu (2013a). A Completion to the Traditions Matrix-Standard - R. T. Craig, Induced by the Transformation of Communication-as-a-Field Membrane in Communication-as-a-Universe Membrane. American International.

[29] Marioara Avram, Aurelia Traistaru, International Letters of Social and Humanistic Sciences 13 (2014) 79-88.

[30] Ştefan Vlăduţescu (2013). The communication membranes. European.

[31] Merleau Ponty M. (1945). Phénoménologie de la perception. Paris: Gallimard.

[32] Andrzej Borowski, International Letters of Social and Humanistic Sciences 6 (2013) 86-90.

[33] Ş. Vlăduțescu (2013). Principle of the Irrepressible Emergence of the Message. Jokull.

[34] Marian Siminică, Aurelia Traistaru (2013). Self-Directed Learning in Economic Education. International.

[35] Florentin Smarandache; Ştefan Vlăduţescu (2014). Neutrosophic Emergences and Incidences in Communication and Information. Saarbrucken: LAP Lambert Academic Publishing.

[36] Janusz Grabara, Michal Kolcun, Sebastian Kot (2014). The role of information systems in transport logistics. International.

[37] Petre Bosun, Janusz Grabara, International Letters of Social and Humanistic Sciences 14 (2014) 59-65.

[37] Vlăduţescu, Ştefan (2008). Comunicarea managerială negativă în activitatea publicistică . Craiova: Editura Arves. 
[38] Andrzej Borowski, International Letters of Social and Humanistic Sciences 4 (2013) 70-74.

[39] Colhon, M. (2013). Automatic Lexical Alignment between Syntactically Weak Related Languages. Application for English and Romanian. In Computational Collective Intelligence. Technologies and Applications (pp. 266-275). Springer Berlin Heidelberg.

[40] Ştefan Vlăduţescu (2013). Message as Fundamental Discursive Commitment of Communication. Journal.

[41] M. Colhon, N. Tandareanu, Annals of the University of Craiova-Mathematics and Computer Science Series 37(1) (2010) 55-70.

[42] Ştefan Vlăduţescu (2014). From Personal and Social Relationships to Social Networks. International.

[43] C. Vintilescu, International Letters of Social and Humanistic Sciences 13 (2014) 58-63.

[44] Petre Bosun, Mirela Teodorescu, Bianca Teodorescu (2014). Corporate Social Responsibility - Collaborating for the Future. International.

[45] Ștefan Vlăduțescu, International Letters of Social and Humanistic Sciences 13 (2014) 71-78.

[46] Andrzej Borowski, International Letters of Social and Humanistic Sciences 3 (2013) 69-74.

[47] I. C. Dima, J. Grabara, P. Pachura, Polish Journal of Management Studies Vol.1 (2010).

[48] Ştefan Vlăduţescu (2013). Three Diachronic Paradigms of Communication. International.

[49] B. M. Dascălu (2014). Echivocul imagologic în Caietele lui Emil Cioran. Studii de Ştiinţă şi Cultură.

[50] V. Tabără (2012). Dezvoltarea capacităţii administrative. Bucureşti: Editura CH Beck.

[51] Sandu Frunză (2014). Advertising and Administration under the Pressure of Ethics. Les Arcs: Editions de la Suers.

[52] Andrzej Borowski, International Letters of Social and Humanistic Sciences 3 (2013) 46-53.

[53] Rajesh K. Yadav, Nishant Dabhade, International Letters of Social and Humanistic Sciences 4 (2013) 49-69.

[54] Jacek Tittenbrun, International Letters of Social and Humanistic Sciences 11 (2013) 10-34.

[55] Ștefan Vlăduțescu, International Letters of Social and Humanistic Sciences 10(2) (2014) 100-106.

[56] Paula Bajdor, Iwona Grabara (2014). The Role of Information System Flows in Fulfilling Customers' Individual Orders. Journal.

[57] Ştefan Vlăduțescu (2013). What Kind of Communication Is Philosophy? Jokull.

[58] A. Țenescu (2009). Comunicare, sens, discurs. Craiova: Editura Universitaria. 
[59] Andrzej Borowski, International Letters of Social and Humanistic Sciences 2 (2014) 110-121.

[60] Aurelia Traistaru, Marioara Avram, International Letters of Social and Humanistic Sciences 13 (2014) 79-88.

[61] Petre Bosun, Vladimir Modrak, International Letters of Social and Humanistic Sciences 14 (2014) 66-72.

( Received 18 April 2014; accepted 24 April 2014 ) 